CATALAN REVIEW

Catalan Review

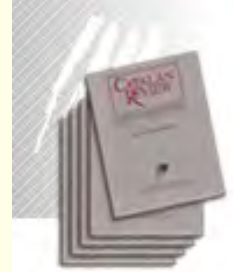

You are accessing the Digital Archive of the Catalan Review Journal.

By accessing and/or using this Digital Archive, you accept and agree to abide by the Terms and Conditions of Use available at http://www.nacs-

catalanstudies.org/catalan review.html

Catalan Review is the premier international scholarly journal devoted to all aspects of Catalan culture. By Catalan culture is understood all manifestations of intellectual and artistic life produced in the Catalan language or in the geographical areas where Catalan is spoken. Catalan Review has been in publication since 1986 .
NORTH

AMERICAN

CATALAN

SOCIETY
Esteu accedint a l'Arxiu Digital del Catalan Review

A l' accedir i / o utilitzar aquest Arxiu Digital, vostè accepta i es compromet a complir els termes i condicions d'ús disponibles a http://www.nacs-

catalanstudies.org/catalan review.html

Catalan Review és la primera revista internacional dedicada a tots els aspectes de la cultura catalana. Per la cultura catalana s'entén totes les manifestacions de la vida intel lectual i artística produïda en llengua catalana o en les zones geogràfiques on es parla català. Catalan Review es publica des de 1986.

\title{
The Sociolinguistic Situation of Catalan at the Turn of the 21st Century: Immigration and Intergenerational Transmission Llorenç Comajoan
}

Catalan Review, Vol. XVIII, number 1-2, (1998), p. 67-95 


\title{
THE SOCIOLINGUISTIC SITUATION OF CATALAN AT THE TURN OF THE ${ }_{2}$ ST CENTURY: IMMIGRATION AND INTERGENERATIONAL TRANSMISSION
}

LLORENÇ COMAJOAN

\begin{abstract}
This article provides an overview of the Catalan sociolinguistic situation at the turn of the $21^{\text {st }}$ century as well as an introduction to the so-called integrationist approach in sociolinguistics, which takes into account issues of social structure and local practice. The article identifies and discusses three main challenges for Catalan: the sociolinguistic situation of the language prior to heightened immigration in the r 990 ; attitudes towards the new immigrants (largely from Africa, Latin America, and Asia), and the intergenerational transmission of Catalan. Each challenge is discussed in light of the current sociolinguistic research based on census data and surveys. The article concludes with a consideration of future prospects for the Catalan language within the changing political and social climate of Spain and Catalonia.
\end{abstract}

\section{AN INTEGRATIONIST PERSPECTIVE FOR THE STUDY OF LANGUAGE IN SOCIETY}

The study of the relationship between language and immigration in
the sociolinguistic situation of a specific language requires research on
how individuals and groups reshape their multiple definitions of terri-
tory, culture, power, and mobility. ${ }^{I}$ Catalan sociolinguistics provides

1. In this paper, I adopt the term "immigrant" following the United Nations' definition of "international migrant:" "any person who changes his or her country of usual residence. A person's country of usual residence is that in which the person lives, that is to say, the country in which the person has a place to live where he or she normally spends the daily period of rest. Temporary travel abroad for purposes of recreation, holiday, business, medical treatment or religious pilgrimage does not entail a change in the country of usual residence" $(17)$. Different countries apply different criteria to define the period of time in the country to be considered an international migrant ( 3 months in Luxembourg, 6 months in The Netherlands, i year in Sweden; Pla Interdepartamental d'Immigració 30 ). The United Nations' definition requires a minimum of 12 months. The term "migrant" in this paper refers to the internal movement and change of residence of Spanish citizens within Spain (mostly from specific areas of Spain to Catalonia in the 1920 and 1960 s of the $20^{\text {th }}$ century). International students, who live in Catalonia for a short period of time as exchange students (through the undergraduate Erasmus 
a good avenue for exploring this relationship, because discussions on language, immigration, and identity in Catalonia have been fairly visible (Pujolar, Immigration I4I).

This essay provides an overview of the current sociolinguistic situation of the Catalan language and pays special attention to the impact of the so-called "new waves" of immigration to Catalonia in the 1990 and beyond. The theoretical perspective here adopted is what Coupland has termed integrationism (9). This section provides a brief characterization of the perspective and shows how researchers in Catalan sociolinguistics can employ it. Specifically, it shows how it relates to matters concerning different groups in Catalan society and the definition of linguistic ideology and ethnicity.

An integrationist perspective transcends the dualism of theories that focus either on fixed social structures (e.g., the relationship between language use and social variables such as age, sex, and social class) or social action and individual agency (e.g., individuals consciously shaping their language in order to achieve specific goals). Instead, an integrationist approach focuses on social behavior; that is, it focuses on the mutual relationships between social structure and local practice. The following three quotes briefly illustrate the questions raised when adopting an integrationist perspective for the analysis of issues related to Catalan sociolinguistics and specific social groups (here, young native Catalan speakers; Catalan and international students, and immigrants from Africa):

(I) És que [els joves] la saben [la Ilengua catalana] i no la fan servir. (Vila, Col.loqui 77). ${ }^{2}$

The thing is that they [the young] know it [Catalan], but do not use it.

(2) En una de las clases que he escogido yo el profesor cambio [sic] de idioma porque no sólo estaba yo sino otros Erasmus. Me parece que no fue un problema para el resto de alumnos, pero de verdad que no tengo idea. (Amblàs 33).

In one of the classes that I chose, the professor changed languages [from Catalan to Spanish], not just because of me but because of other Erasmus students. I don't think that it was a problem for the rest of the students, but I really have no idea.

(3) Con mis hermanos hablo castellano, a veces hablo árabe, cuando estamos

program) or as students pursuing graduate degrees, are also discussed in this paper because their growing presence in Catalan universities has linguistic repercussions that ofren remain understated in discussions of the sociolinguistic situation of Caralonia.

2. All translations from Catalan and Spanish into English are by the author. 
enfadados; nosotros en árabe no sabemos hablar en cachondeo y eso [...] el catalán no lo suelo hablar, excepto cuando es muy, muy necesario, en la clase. Me parece muy pesado, muy raro de pronunciar. En cambio a mis hermanos pequeños, que desde los 3 años y antes están aquí, sí lo hablan y les gusta. (Siguan 193)

With my brothers I speak Spanish, though sometimes I speak Arabic, when we are angry; we do not know how to joke around in Arabic and [...] I do not usually speak Catalan, except when it is very, very necessary, in class. Catalan seems very heavy, very strange to pronounce. On the other hand, my younger brothers, who have been here since the age of 3 or earlier, speak it and like it.

The first quote is from a comment by a member of the audience at a conference on the use of Catalan among young people in Catalonia. It echoes the oft-heard comment by older and younger Catalanspeaking generations that young people whose native language is Catalan and who have been schooled in Catalan know the langauge but do not use it in interpersonal relationships. The quote makes reference to a traditional sociolinguistic variable (youth versus adults and intergenerational transmission), but it also refers to the use of a language outside of institutionalized contexts, specifically, outside the classroom and in practices such as going out to clubs and playing the so-called gender and identity game. ${ }^{3}$

The second quote comes from one of the participants in Amblàs study on the use of Catalan and Spanish as the language of instruction in university classrooms for Erasmus students from other European countries, many or most of whom do not speak Catalan. An integrationist perspective of social and linguistic theories would here take into account social structure, including such issues as the co-official status of Catalan and Spanish in the university system in Catalonia and the financial pressures for universities to open their doors to international students in order to counterbalance the low numbers of Catalan students and the high numbers of faculty members. In addition, the integrationist approach takes into consideration local practices shaped by the power relationships between professors and students (for instance, what is the impact of using on an exam a language that is not the language of instruction?); the possibilities for students from different geographical areas to study abroad; and the practices within specific schools and disciplines (why are certain disciplines in certain universities taught in Catalan and others in Spanish?). An integrationist approach is of relevance when studying language and immigration, especially in multilingual situations with minority languages: Catalan and Spanish as they relate to matters of gender and identity. 
The third quote comes from a I6-year-old girl from Tangier in Barcelona (Siguan 193). The girl's statement summarizes the well-known sociolinguistic process of language shift: the girl indicates that she is losing her native language (Arabic) - which she can no longer use for specific functions, such as joking - to Spanish, but not to Catalan. An integrationist perspective examines how language shift takes place in local environments where more than one language is present and where gender and generational characteristics are prominent (e.g., what are the roles of Muslim women and men as agents of intergenerational transmission in multilingual societies? What are the socialization patterns between children from Morocco and local children [Catalanor Spanish-speaking] in Barcelona schools?).

In sum, these three quotes point to the need "to relate the microculture of communicative action to political economic considerations of power and social inequality, to confront macrosocial constraints on language behavior, and to connect discourse with lived experiences" (Woolard 27). From a similar perspective, they are instances of linguistic ideology, understood as a "rationalization or justification" (Silverstein 193) of what language users do with the languages they know or learn. An integrative approach that examines language acquisition/use and immigration should incorporate definitions of ethnicity that are compatible with a focus on social structures and local practices and should provide a critical take on the tenets of both essentialism and constructivism in order to transcend reductive dualisms. This paper adopts Day's and McAndrew's definitions of ethnicity because these researchers work within multilingual areas with large immigrant populations (New Zealand and Canada, respectively) and take into account the role of the individual, the power relationships among groups, and the relationship between agency and structure. McAndrew defines ethnicity as the "combined production of external and internal boundaries and of the mediation by the Subject" (par. 16), while Day (10) draws on Pierre Bourdieu's concept of babitus: "[e]thnicity needs to be viewed both as constructed and as a social, political and cultural form of life. In this sense, ethnic identities are not simply representations of some inner psychological state, nor even particular ideologies about the world... Rather, they are social, cultural, and political forms of life -material ways of being in the modern world" (1o, emphasis in the original).

These definitions gesture to the complexity of ethnicity and strive to avoid the "pensament de dicotomies" (Bastardas, Politica 4 ) that plagues so many discussions of language and ethnicity. In Catalan sociolinguistics, dichotomous thought manifests itself periodically in, among other things, the "deliri prolèptic" (Murgades 80) of the socalled optimists and pessimists who engage in discussions of the "life" 
and "death" of the Catalan language. This article adopts neither an optimistic nor a pessimistic perspective regarding the future of Catalan, but rather attempts to negotiate both in order to describe a sociolinguistic situation affected by the profound changes within Catalan society at the beginning of the 2ist century.

\section{CHALLENGES}

The interaction of individuals is complex and dynamic, and rapid changes - such as immigration from outside the European Union to Spain and Catalonia since the rg9os- present challenges both to society in general and to individuals' social roles and positions. In uneven, multilingual contexts such as that of Catalan, the situation is especially acute, because an increase in the number of speakers of the dominant language (Spanish) can be an obstacle to the maintenance, let alone expansion, of the dominated language (Catalan).

Rapid demographic changes such as those experienced by Spain at the turn of the century (between 1997 and 2001 the population of immigrants doubled) obviously raise questions, for both individual citizens and governments, as to what society was like before and what it may become. Both questions - with the second veering towards interculturality - are fraught with illusions because, as ZapataBarrero has argued with respect to Spain, immigration is neither a problem nor an ideal, but rather an "irreversible process" (ro). Thus, because immigration appears to be irreversible, the word "challenge," as it is used in this paper, might best be understood by way of the Catalan word repte: "objectiu difícil que constitueix un estimul i un desafiament per a qui se'l proposa." 4 In other words, immigration to Catalan-speaking areas might best be seen as a stimulus to evaluating the impact of previous migrations (e.g., internal Spanish migration in the $1960 \mathrm{~s}$ ); to examining the manner in which current population movements from outside the European Union configure new forms of society; and to envisioning models that accommodate future migrations. With respect to immigration and the Catalan language, there are three basic questions or challenges: the sociolinguistic situation of Catalan prior to the increased immigration of the r 990 ; local and national attitudes towards the immigrants who arrived during those years, and the intergenerational transmission of Catalan.

4. "[A] difficult goal that is a stimulus and a challenge for the person who has it" (Gran diccionari de la llengua catalana). 
The Sociolinguistic Situation of Catalan Prior to the New Waves of Immigration in the $1990 \mathrm{~s}$

The sociolinguistic situation of Catalan can be described from both a macrosociolinguistic and a microsociolinguistic perspective. 5 From a macrosociolinguistic perspective, the evolution of census data (1986, $1991,1996,2001$ ) shows a clear increase in the knowledge of Catalan among the inhabitants of Catalonia in all four basic skills: speaking, understanding, reading, and writing (Table r). For instance, the ability to write Catalan rose from $31.6 \%$ in 1986 to $49.8 \%$ in 2001 , while the ability to speak the language rose from $64.2 \%$ in 1986 to $74.5 \%$ in 200I.

\begin{tabular}{lcccc}
\hline & Understanding & Speaking & Reading & Writing \\
\hline 1986 & 90.6 & 64.2 & 60.7 & 31.6 \\
1991 & 93.8 & 68.3 & 67.6 & 39.9 \\
1996 & 94.9 & 75.3 & 72.4 & 45.8 \\
2001 & 94.5 & 74.5 & 74.4 & 49.8 \\
\hline
\end{tabular}

Table t. Percentages of knowledge of Catalan in Catalonia according to Spanish census data (Idescat, Cens).

Census data need to be examined from a geographic (or geopolitical) perspective, because the distribution of population in Catalonia is uneven: more than half the population of Catalonia lives in Barcelona and its metropolitan area. Map I, based on 2001 census data, displays the geographic distribution of the population that speaks Catalan (age 2 and older). Three main linguistic areas can be observed in the map: in the Barcelona metropolitan area, approximately $75 \%$ of the population speaks Catalan; in the northern coastal area and its surroundings, the percentage ranges between 75 and $85 \%$, and in the interior/northern area of Catalonia, as well as in the west and the sourheast, the percentage is over $85 \%$. As noted by Junyent in an analysis of maps with data from the 1996 census, no coastal area of Catalonia (except for Terres de l'Ebre) displays more than an $85 \%$ usage rate of Catalan ("Catalä" I4O-43). In sum, even though the overall census data can be interpreted as evidence that almost all the population of Catalonia understands Catalan, the geographical data indicate that the most populated areas of Catalonia are the ones with the lowest rates of knowledge. Junyent contrasted, moreover, data on

5. The number of sociolinguistic surveys and studies on Catalan carried out by the Direcció General de Politica Lingisistica and orher organizations has notably increased in the last ten years; see Romani and Torres (Enquestes) for a summary. 
sociolinguistic maps from Wales and Catalonia, and ventured that the Catalan-speaking areas of Western Catalonia (with high levels of knowledge of Catalan) were slowly coming to resemble those areas with lower levels of knowledge of Catalan (in the visual lexicon of the map, the darker Western areas are becoming grayer) ("Català" I42).

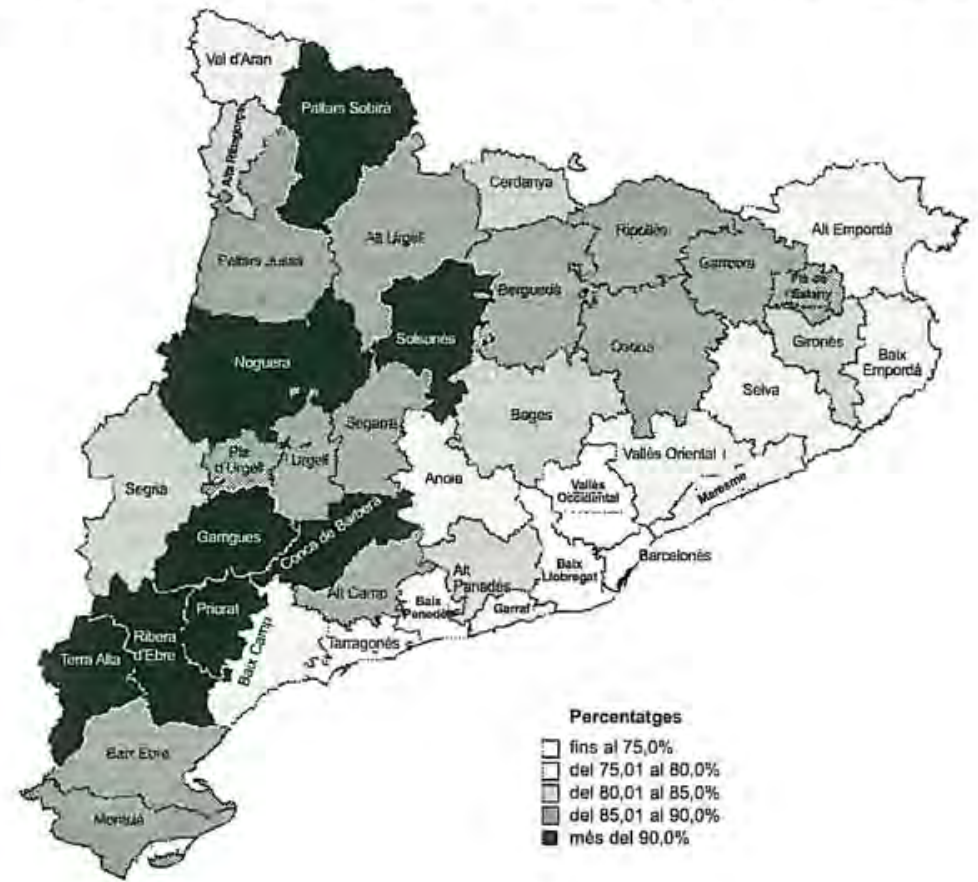

Map I. Geographical Distribution of Knowledge of Spoken Catalan According to the 2001 Census Data (the darker the area, the higher the knowledge of spoken Catalan; Idescat, Cens).

Census data reflect individuals' perceptions of their knowledge of Catalan, but they do not provide a detailed analysis of the actual use of Catalan in different domains of society. ${ }^{6}$ The data from the 2001 census show that $74.5 \%$ of the Catalan population spoke Catalan, but this information is of little use unless we know when, with whom, and in what situations. The Estadistica d'Usos Lingüistics (EUL) conducted in 2003 attempted to fill this void and surveyed the use of

6. Census data are also problematic because of the (socio)-methodological constraints that obtain in gathering them (see Cruscat, for a discussion of the methodological problems in the Spanish 2001 census). 
Spanish and Catalan in different social environments. The EUL data are not comparable to census data, because the EUL was based on a sample of only 7,257 people ( 15 and older) who answered questions over the phone. Nonetheless, the EUL provides a more detailed analysis of the use of Catalan than the census. Interestingly, the EUL distinguishes between the primary language spoken at home, the language of identification, and the habitual language. The three definitions of language in the EUL were as follows: I) "Primera llengua" (first language) or the language that the interviewee spoke first at home (it was considered the language transmitted within the family); 2) "Llengua pròpia" (language of identification) or the language that the interviewee considered to be his or her language and with which he or she identified; and finally, 3) "llengua habitual" (habitual language) or the language that the interviewee used more often (Estadistica 15-16). The results show that on the whole the Catalan population divides itself into individuals who use predominantly either Catalan or Spanish, with a minority who mention both languages as their first, habitual, and/or language of identification (Table 2).

Catalan Spanish Both

First

Habitual

Identification
40.4

50.1

48.8
53.5

44.1

$44 \cdot 3$
2.8

4.7

5.2

Table 2. Percentages of first, habitual, and identification language in Catalonia (Estadística d'Usos Lingiüistics, Idescat, Estadística).

The fact that $40.4 \%$ of the population stated that Catalan was their first language and that $50.1 \%$ of the population stated that Catalan was their habitual language can be interpreted as evidence that the Spanish migrant population is slowly adopting Catalan as one of its languages. ${ }^{7}$ This trend is confirmed in the geographical distribution of the data: the

7. Internal migration from other areas of Spain to Catalonia in the early $20^{\text {th }}$ century took place in two main periods. The first period was the ra2os, when people mostly from Murcia and Almeria (and to a lesser degree from Aragon and Valencia) migrated to Catalonia to complete public works in construction (for instance, the Universal Exposition of 1929) and in mining. The second period was the 1960s, marked by industrialization and economic expansion. For instance, between 1966 and 1970, Catalonia's net migration rate (difference between immigration and migration) was 365,481 . The migrants during the second period were mainly from Andalusia and settled in the Barcelona metropolitan area (Termes 129-39). 
percentage of Catalan as a habitual language is higher than Catalan as a first language in all geographical areas, whereas the opposite is true for Spanish (Table 3$)^{8}$

Catalan

Spanish

Both

First Habit. Ident. First Habit. Ident. First Habit, Ident.

Barcelona and

metro area

Girona area

Tarragona area

Ebre area

Lleida area

Central area

Pyrenees area

Catalonia

\begin{tabular}{rrrrrrrrr}
31.9 & 41.5 & 40.2 & 61.5 & 52.1 & 52.1 & 3.1 & 5.3 & 5.9 \\
59.7 & 70.3 & 67.3 & 35.3 & 24.8 & 26.2 & 1.7 & 3.6 & 4.4 \\
46.4 & 54.4 & 53.4 & 48.4 & 41.1 & 40.6 & 2.4 & 3.9 & 4.8 \\
81.2 & 89.4 & 88.9 & 13.5 & 7.4 & 8.9 & 1.3 & 1.4 & 0.5 \\
65.7 & 76.5 & 75.5 & 29.7 & 20.1 & 21.8 & 2.7 & 3.0 & 2.4 \\
61.1 & 72.2 & 71.0 & 35.4 & 23.8 & 23.7 & 1.9 & 3.5 & 3.8 \\
62.2 & 71.7 & 71.3 & 30.4 & 20.3 & 21.0 & 0.7 & 2.6 & 1.9 \\
40.4 & 50.1 & 48.8 & 53.5 & 44.1 & 44.3 & 2.8 & 4.7 & 5.2 \\
\hline
\end{tabular}

Table 3. Percentages of use of Catalan as a first, habitual, or identification language by geographical areas (based on data from the Estadistica d'Usos Lingüistics, Idescat, Estadistica).

The EUL provides data on the reported levels of use of Spanish and Catalan in specific situations. Table 4 shows the data on the exclusive use of Catalan by geographical area and situation.

The data in Table 4 show that exclusive use of Catalan in different situations never surpasses $50 \%$ for the entire Catalan population (the highest percentage of use is in banking, when addressing medical staff, and when talking to strangers). The lowest percentages of exclusive use are in the Barcelona metropolitan area (with friends $16.1 \%$, with neighbors $19.5 \%$, with school colleagues $19.3 \%$, and with work colleagues $20.7 \%$ ). A comparison of the exclusive use of Catalan in specific situations suggests that the use of Catalan as a habitual language in Table 2 may be exaggerated, given that only one of the situations in Table 4 (banking, $40.5 \%$ ) approximates the general percentage use of Catalan as the habitual language (4I.5\%, Table 3).

In shifting our lens from the whole of Catalonia to specific geographical areas, we now turn to two instances of Catalan language

8. The early analyses of the geographical data of the Estadistica d'Usos Lingüistics. were not distributed into age groups, and thus it was not possible to assess the intergenerational transmission of Catalan and Spanish. 
Barcelona Girona Tarragona Ebre Lleida Central Pyrenees Total and metro area area area area area area Catalonia area

Household

\begin{tabular}{|c|c|c|c|c|c|c|c|c|}
\hline members & 28.0 & 59.3 & 41.8 & 79.8 & 63.1 & 59,0 & 58,2 & 37.2 \\
\hline Friends & 16.1 & 44.9 & 26.3 & 66.2 & 51.0 & 45.7 & 42.7 & 24.5 \\
\hline Neighbors & 19.5 & 53.4 & 32.3 & 77.5 & 60.7 & 55.5 & 54.7 & 29.5 \\
\hline \multicolumn{9}{|l|}{ School } \\
\hline \multicolumn{9}{|l|}{ Work } \\
\hline colleagues & 20.7 & 44.6 & 27.1 & 63.1 & 48.8 & 45.1 & 48.1 & 27.5 \\
\hline Small stores & 26.6 & 60.9 & $39 \cdot 3$ & 69.5 & 57.9 & 60.3 & 56.2 & 35.6 \\
\hline \multicolumn{9}{|l|}{ Department } \\
\hline stores & 24.9 & 55.6 & 34.1 & 6r.I & 50.9 & 54,4 & 49.1 & 32,6 \\
\hline Banking & 40.5 & 73.5 & 49.9 & $7^{78.1}$ & 72.9 & 75.5 & 72.3 & 49.2 \\
\hline Medical staff & 33.0 & 65.2 & 42.9 & 65.4 & 60.4 & 66.5 & 60.3 & $41 . I$ \\
\hline Strangers & 30.3 & 62.7 & 44.2 & 74.0 & 67.2 & 62.7 & 64.0 & 39.5 \\
\hline Personal & & & & & & & & \\
\hline written notes & 24.6 & 51.4 & 34.6 & 48.8 & 49.1 & 51,0 & 43.1 & $3 \mathrm{I} .4$ \\
\hline
\end{tabular}

Table 4. Percentages of exclusive use of Catalan in different geographical areas and social domains (based on data from the Estadistica d'Usos Linguiistics, Idescat, Estadistica).

use among children (microsociolinguistic level). Vila investigated the social use of Catalan in schools and posed the following question: "Hem guanyat l'escola però hem perdut el pati?," that is to say, "We have won the school, but have we lost the playground?" (Guanyat). The first part of the question refers to the fact that the presence of Catalan in schools (in comparison to the dictatorship and democratic transition years) has increased due to the implementation of linguistic policy laws since the early $1980 \mathrm{os}$. For instance, in $1986-87,24 \%$ of preschools and primary schools taught in Catalan, compared to $68 \%$ in 1995-96. Vila expressed his concern about the social use of Catalan (in the playground, as opposed to in the classroom) in the following manner:

Si per 'guanyar l'escola' $s$ 'entén fer del català l'única llengua vehicular de doència a (pràcticament) totes les escoles de Catalunya de la mateixa manera que el castellà ho és a Andalusia o Castella, no es por dir que s'hagi assolit aquest objectiu. Si en canvi per 'guanyar l'escola' s'entén convertir el català en la llengua vehícular àmpliament predominant a la gran majoria de centres escolars de 
Catalunya, aquesta fita sembla a grans trets assolida a l'ensenyament primari, i pendent encara al secundari, ' (Guanyat II)

In a further study, Vila investigated language use by children in school playgrounds and found that the distribution of languages was clearly in favor of Spanish (60\%, as opposed to $34 \%$ for Catalan). ${ }^{\text {Io }}$ Vila noted, however, that the data must be analyzed from a historical perspective and that they were not necessarily evidence for a decrease in the use of Catalan; instead, he argued, they suggest a problem of perception of social reality in moments of important social change. In the case of Catalonia, social change at school was evident because Spanish-speaking individuals of the early migrations to Catalonia (in the 1960s) were never schooled in Catalonia and because the patterns of interaction between native and non-native Catalan children in the playground were changing with the arrival of speakers of languages other than Catalan. According to Vila, these changes in social interaction contributed to the perception among sociolinguists, educators, and the public in general that the actual use of Catalan in society was very low when, in reality, the decrease of Catalan in playgrounds had been happening since the 1940 s and sos. Vila conceded that the decrease was probably a mirror image of what was happening on the streets of Catalonia, and he argued that it was naive to imagine that making Catalan the language of instruction in schools would perforce increase the social use of Catalan - as if the role of schools were more decisive than that of society at large.

In sum, the first challenge for the current sociolinguistic situation of Catalan and its speakers appears to have little to do with recent waves of immigration; instead, it is part of the longstanding sociolinguistic situation of a minority (or minoritized) language in the context of a hegemonic language.

\section{New Immigration to Catalonia: Who is the Other?}

Until recently, immigration in Catalonia involved two general groups: migrants from within Spain (specifically, in two major waves: 19I4-

9. "If by 'winning the school' one understands making Catalan the only language of instruction in Catalonia in the same manner that Spanish is the only language of instruction in Andalusia or Castile, we cannot say that we have reached this goal. On the other hand, if by 'winning the school' one understands to make Catalan the mostly predominant language of instruction in most of the schools in Catalonia, this yardstick seems to have been reached for primary schools, but still pending in secondary schools."

10. In the remaining cases (10\%), it was not possible to establish whether Catalan or Spanish were used. 
1929 and 1950-1975) and gypsies (Samper Rasero et al. 135). A new wave of external immigration, comprised largely of Africans and Latin Americans, began in the I990s. The two main characteristics of the new external immigration were that Catalonia was one of the areas that received the most immigrants and that the new immigrants arrived quickly. For instance, in 2002, four of the seventeen Spanish autonomous communities received approximately $70 \%$ of foreigners: Madrid (22.5\%), Catalonia (19.3\%), Valencia (15.2\%), and Andalusia (เo.7\%) (Instituto Nacional de Estadística). Furthermore, the distribution of immigrants within a given autonomous community was also uneven: in Catalonia, new immigrants reside mostly in Barcelona, where they made up $12.8 \%$ of the population in 2004 . As for the pace of arrival of immigrants, in a first "etapa tranquila" or "calm period" (Alonso 12), the number of immigrants to Catalonia from outside Spain was small $(60,800$ foreigners in $1981,1 \%$ of the population), but a dramatic increase in the arrival of immigrants took place at the end of the I990s: between 1997 and 2000 the average number of new residents in Catalonia was 39,000 (compared to $\mathrm{II}_{5} 500$ between 1991 and 1997) (Alonso 13). As with linguistic data culled from the census, numerical data on immigrants need to be taken with some caution. The most common sources for data on immigration are the national census, the municipal census (padró municipal), and the police registry (residents). Recolons analyzed all three types of information and described immigration in terms of "doublings" of population over different periods. The first doubling in Catalonia (from 15,000 to 30,000 ) took place over eight years (196I-1969); the second took twenty years (1969-1989) (60,000); the third took place between I991 and 1997, and finally, in just four years (up to 2001), the population doubled again $(280,000)$.

The arrival of immigrants since the rggos affected Spanish and Catalan society in many ways, with changes in the school system being of particular importance. As Delgado has argued, biological racism is not the ideology responsible for most discrimination in western societies (II). However, cultural racism has inherited some of the "genetic" characteristics of biological racism and has transferred them to the notion of culture. At any rate, whether one type or another, instances of racism are hardly difficult to find in Spanish newspaper headlines or in sociological data - as well as in daily life. For instance, in a survey of 1,492 Spanish young people (aged $15-29$ ) in 2002 (CIS 2458), participants were asked the following two questions: "How would you say that Spaniards, in general, treat foreign immigrants?" and "More specifically, how do Spanish youth treat immigrants?" The results are presented in Table 5 . 
Spaniards in general

Spanish youth

With disdain

20.9

2I.I

With agressivity

2.9

II. 8

With distrust

53.4

32.6

With indifference

12.9

20.4

With kindness

As if they were Spaniards

4.6

5.8

Do not know

2.1

4.0

No answer

2.7

3.6

0.5

0.7

Table 5. Attitudes towards immigrants (based on questions 23 and $24, \mathrm{CIS}$ ).

The data show that young people report differences between how they and Spaniards in general treat immigrants (e.g., a difference of $53.4 \%$ and $32.6 \%$ regarding distrust). The fact that the survey presented the participants with four negative characteristics and only two positive ones may have biased the results, but it is nonetheless clear that young people have, in general, a negative opinion of immigrants. The data are confirmed in a more straightforward question in the same study (question 27, CIS): "Do you think that, in general, Spaniards are racist?" Sixty-eight percent of the participants answered "yes."

The Catalan school system went through a series of important changes affecting the language of instruction even before the arrival of recent immigrants. In the early period of implementation of linguistic laws, ${ }^{12}$ educators in the Catalan school system had attempted to bring together children with two different first languages (Spanish or Catalan), but with the new migrations of the 1990s, the make-up of the schools has changed dramatically. Neither the central nor autonomous governments in power at the time adequately anticipated the social, educational, and linguistic consequences of rapidly increasing numbers of new students from diverse ethnic, linguistic, and socioeconomic backgrounds. For instance, in $2003,8.1 \%$ and $9.0 \%$ of pre-school and primary school children respectively were foreigners, mostly from

II. The complete results were: yes $(67.6 \%)$, no $(26.1 \%)$, do not know ( $5.3 \%)$, and no answer $(1.0 \%)$.

12. Legislation in the implementation of Catalan as the language of instruction in schools in Catalonia is vast (see Vernet et al., Chapter 8). The Llei de Normalitzacio Lingüistica of 1983 and several decrees stated that children were to be schooled in their habitual language and that Catalan was to be used progressively as the language of instruction. The Llei de Politica Lingiuistica of 1998 reaffirmed Catalan as the language of instruction of primary and secondary education in Catalonia. 
North Africa and Latin America. Faced with such momentous changes, the Catalan school system had to react quickly and consider how to address diversity.

Since the transition to democracy, there have been two political processes of cultural diversity in Catalonia (Pascual ing-28). In the 1980s, the implementation of linguistic policies and laws directed at immigrants and, more generally, at non Catalan-speaking populations sought linguistic integration. In that decade, the "management of cultural difference" was directed at ethnic minorities, most notably, gypsies and, later, Africans. The 19gos brought the discourse of interculturality to Spain and Catalonia. ${ }^{\text {I3 }}$ Pascual evaluated the evolution of interculturality in Catalonia and differentiated between what he calls strong and weak intercultural positions. The so-called weak position considers the new situation in terms of "them" or "the others." This was the policy adopted by the government and educators in the $1980 \mathrm{~s}$ and early rg9os, with different programs of compensatory education. The main drawback of this policy, according to Pascual, was the "risc de contagi simbòlic entre diversitat cultural, marginació social i dèficits escolars" ("risk of symbolic contamination between cultural diversity, social marginalization, and school deficit," 122). In other words, the motto was "canvia el mínim imprescindible perquè tot continuil igual" ("change the minimum necessary so that everything stays the same," I23). In contrast, the so-called strong position towards interculturality does not view the new situation in terms of "them" and "the other," but rather in terms of a more expansive and accommodating "us." For this reason, intercultural education is a process that involves the entire society (e.g., health care, the mass media, and labor) and not just schooling. According to this position, education is not compensatory or marginalizing (i.e. only for some), but for everybody.

In his analysis of the Catalan school system at the beginning of the $21^{\text {st }}$ century, Pascual concluded that it still followed the weak model but that there were some trends toward a strong program of intercultural education. In this respect, the governmental changes that occurred in Spain and Catalonia in 2003-2004 are likely to have an impact on immigration and linguistic policy, given that the governing

13. I follow the common distinction between multiculturalitat (translated in this paper as "multiculturality") and interculturalitat (translated as "interculturality") as defined by Beltrán. Multiculturality tends to naturalize cultures and keep them isolated from each other in a specific environment; whereas interculturality, or pluriculturality, is based on a dynamic, reciprocal relationship among different cultures. In language and education policy, interculturality is also referred to as pluriculturalismo. For instance, Hamel, when discussing language policy in indigenous Latin America, discusses three chronological periods: monoculturalismo or denied diversity, multiculturalismo or diversity as a problem, and pluriculturalismo or enriching diversity. 
parties in Catalonia made specific campaign promises about immigration policy (e.g., offices representing the Catalan government in immigrants' countries of origin and more balanced funding for social services in accordance with the number of immigrants from each geographical area) and reforms in the laws governing the relationship between Catalonia and the Spanish central government (the new Estatut). ${ }^{\mathrm{I} 4}$ The Catalan government that came to power in 2003 is well aware of the importance of immigration and has produced a rich body of documents on immigration as it bears on welfare and the family (Pla de Ciutadania i Immigració 2005-2008), education (Pla d'Actuació per a l'Alumnat de Nacionalitat Estrangera 2003-2006), and language policy (Pla per a la Llengua i la Cobesió Social). These documents constitute a good step towards a better outlook for immigrants in Catalonia, because they tend to involve all members of Catalan society, whether immigrants or not. With regard to the Catalan language, however, the aforementioned documents and initiatives will be of little use unless they take into consideration findings from earlier periods and sociolinguistic situations and unless they involve individuals, private businesses, and governmental institutions.

The image that comes to mind among many citizens when discussing immigration to Catalonia is often that of an (illegal) African or Latin American in search of better living conditions. There are, however, other images. For example, the movie L'Auberge Espagnole (interestingly translated as Casa de locos in Spain, and Euro Pudding and Pot Luck for the English-speaking audiences) provides a glimpse into the life of another type of foreign resident in Barcelona: the generally clean-cut, trendy, European university student in the Erasmus exchange program. In one scene, an Erasmus student stands up in a university classroom in Barcelona and asks the professor to speak in Spanish instead of Catalan. The professor does not hesitate to reply that Catalan is the official language of Catalonia and recommends that the student go to Madrid or Latin America if she wants to study in Spanish.

What may seem to be an unlikely scene in a movie is, in fact, increasingly common, inasmuch as Catalonia, together with Andalusia and Madrid, is one of the autonomous communities that receives the largest number of foreign university students. The arrival of foreign students to Catalan universities, concentrated in Barcelona, began in the late 1980s, when the Erasmus program was initiated, and it has

14. In 2003, after 23 years of center-conservative nationalist governments in Catalonia, a coalition of socialists, independentists, and eco-socialists came into power. In 2004, the Partido Socialista Obrero Español won the Spanish legislative elections after eight years of a conseryative government under the Partido Popular. 
continued to grow in the early years of the $2 \mathrm{r}^{\mathrm{st}}$ century. For instance, in the 2003-04 academic year, foreign students at the graduate level (tercer cicle) accounted for $40 \%$ of the total student body taking graduate courses at the Universitar Pompeu Fabra, $51 \%$ at the Universitat Politècnica de Catalunya, $25 \%$ at the Universitat de Barcelona, and $20 \%$ at the Universitat Autònoma de Barcelona (Ministerio de Educación y Ciencia). At first, universities were caught off guard, and few offered any support for foreign students, but soon they realized that existing linguistic laws and university regulations were not enough for day-to-day interactions between professors and students inside and outside the classroom. Accordingly, Catalan universities created language programs for foreign students (programes d'acollida) in order to ensure that the presence of these students would not hinder the use of Catalan among native students (Casals 43).

Although the number of foreigners in Catalan universities is small compared to the number of foreigners in primary and secondary schools, they nonetheless can have a determining impact on the use of Spanish in both curricular and extracurricular contexts (when natives and non-natives are present). For instance, in a study at the School of Political Science and Sociology at the Universitat Autònoma de Barcelona in $2000-2001,77 \%$ of native university students and $60 \%$ of professors admitted that the presence of foreign students had affected - that is to say, changed - the language of instruction (Amblàs). An impressively large proportion of students (some $85.9 \%$, to be precise) reported that they had taken, or were taking, classes with Erasmus students and that the presence of these students had involved a change in the language of instruction from Catalan to Spanish; tellingly, $65.3 \%$ said that they were not bothered by the change of language. Some of the responses were as revealing as they were divergent: $70.1 \%$ of local students said that they thought that foreign students did not have enough knowledge of the linguistic environment (i.e., the use of Catalan and Spanish as languages of instruction at the university level); most of the foreign students $(85 \%) \mathrm{knew}$, however, that there were two languages in Catalonia; and $21.6 \%$ of professors said that they would change from Catalan to Spanish if asked to do so. ${ }^{15}$ Branchadell and Pujol, for their part, have argued that Catalan universities are nor sufficiently explicit in informing their students that in Catalonia there is not a dual language system (universities that exclusively teach in specific languages, as in Montreal), which may explain why students asked professors to change language even though they know that both

I5. The fact that $60 \%$ of professors reported that they had changed the language of instruction challenges the result that only $21,6 \%$ of professors said that they would change the language of instruction if asked by an Erasmus student. 
Spanish and Catalan have official status in Catalonia. In order to avoid and ameliorate such confusing situations, Branchadell and Pujol recommend that faculty be more aware of the sociolinguistic situation of Catalan and that universities implement offices that can provide better service to international students.

In sum, the impact of "new immigration" on the Catalan language cannot be divorced from the changing sociopolitical reality of Spain and Catalonia. The Catalan educational system is moving toward a strong intercultural system that implicates the whole of Catalan society, even though the level of racism in Spain and Catalonia still renders any optimistic viewpoint suspect.

\section{Intergenerational Transmission of Catalan}

Intergenerational transmission is arguably the most decisive challenge that minority languages face, and it must be the main focus of attention if the process of language shift (from Catalan to Spanish) is to be reversed (Fishman, Reversing 368, Threatened, 465-68). ${ }^{16}$ In environments where such language shift is taking place, Fishman's Graded Intergenerational Disruption Scale is a useful tool for analyzing the direction of the process (between the total disruption or disappearance of the language and its cultural autonomy) as well as the actions to take in order to reverse disruption. In the Graded Intergenerational Disruption Scale, the threatened language is positioned at one of a total of eight stages according to the language's level of disruption in specific social spaces (mass media, education, family, and so on). Stages 8-5 lead to a diglossic situation (in which languages are "specialized" for specific social spaces), while stages $4-1$ lead to full vitality of the language. The key to moving beyond diglossia and to reversing language shift can be found at stage 6: intergenerational transmission from parents to children. As obvious as Fishman's insistence on intergenerational transmission may be, many processes of language revitalization have not focused on intergenerational transmission, targeting instead schooling and mass media.

Upon analyzing the contemporary linguistic situation, Fishman concluded that Catalan in Spain -along with French in Quebec and Hebrew in Israel-consrituted a successful case of a revitalized language;

16. Fishman's theory of reversing language shift is defined as follows: "[ $t]$ he theory and practice of assistance to speech communities whose native languages are threatened because their intergenerational continuity is proceeding negatively, with fewer and fewer users (speakers, readers, writers and even understanders) or uses every generation" (Reversing $\mathrm{I}$ ). 
that is, it was at stage $\mathrm{i}$ of the disruption scale (Reversing 287-336). Catalan sociolinguists subsequently evaluated Fishman's claims regarding Catalan and found that while it was useful in general, it was nonetheless problematic in many aspects, namely its emphasis on the individual speaker of Catalan instead of the political institutions; the diminished role given to education as an agent of language revitalization; the hierarchical ordering of the stages; and its conformity with a territorial model of bilingualism (Boix and Vila 302-I4). More specifically, Strubell argued that an analysis of the sociolinguistic situation of Catalan needed to take into account other factors, such as the role of the mass media, politics, and demography. Despite these reservations, and in the light of Catalonia's demography and the current influx of immigrants, it is important to consider how trends in population growth affect the intergenerational transmission of Catalan.

In the last decades of the zoth century, Catalonia had a low natural population growth: 11.6 in $1975,2.3$ in $1986,0.7$ in 1990 , and 0.03 in 1995 (Idescat). ${ }^{17}$ However, after 1996, the arrival of immigrants contributed to important demographic changes. For instance, between 1996 and 200I, the population of Catalonia (aged 2 and older) increased by 230,000 inhabitants, 207,000 (i.e., almost $90 \%$ ) of whom were from outside Spain (Noves SL, Presentació). Low fertility and birth rates in Catalonia ( $\mathrm{I} .3$ and II.I in 2003 , respectively) are nowadays counterbalanced by an increase in the number of births from couples in which one or both parents are foreigners: $80 \%$ of new births in 2003 occurred among couples in which both parents were from Spain, while more than half of new births between 2002-03 were among couples in which one or both parents hailed from abroad (Idescat, Naixements). ${ }^{18}$

The transmission of a language can be studied at an intergenerational level (the family) and at an interpersonal level (social communication between speakers). In order to have a better assessment of the current situation, it is useful to examine previous periods of migration to Catalonia (specifically, the migration of Spanish-speaking citizens to Catalonia in the 1960s), and the status of intergenerational transmission. Overall, the data show that since the massive arrival of Spanish migrants in the 1960 , being born in Catalonia no longer presupposes that one will speak Catalan, as was the case in previous decades. Torres

17. The natural growth rate of a specific area and period provides a measure of the increase or decrease of population. It is calculated by subtracting the death rate from the birth rate (both calculated for every $\mathrm{t}, 000$ individuals).

18. The percentage variation in the number of births between 2002-03 in Catalonia was: 3.5 (both parents from Spain), 18.4 (father from Spain, mother from abroad), 3.9 (mother from Spain, father from abroad), 30.1 (both parents from abroad), 7.5 (no information on the parents' nationalities) (Idescat, Naixements). 
analyzed demographic trends in the $20^{\text {th }}$ century and found four apparently contradictory results regarding the oral use of Catalan at home $(U s)$. First, the use of Catalan as the first language at home decreased; second, parents spoke more Catalan to their children than they did to their own parents; third, census data of schools show that the presence of Catalan increased; and fourth, the use of Catalan by adults decreased. Torres explained these results by appealing to the different birth rates for the two linguistic groups here in question, Spanish and Catalan $\left(U_{s}\right)$. Non-Catalan Spaniards who migrated to Catalonia between 1955 and 1977 had more offspring upon their arrival than Catalans. This explains why the use of Catalan at home did not increase among young people, even though parents as a whole reportedly spoke more Catalan with their offspring than they had with their parents. The differences in the trends and birth rates among the different linguistic groups decreased in the last decades of the $20^{\text {th }}$ century, which accounts for the increase of Catalan as a family language among the youngest individuals. Finally, both groups (people who migrated from other areas of Spain to Catalonia and people from Catalonia) are having fewer offspring at the beginning of the $2 \mathrm{I}^{\mathrm{st}}$ century, but natality in the Spanish-speaking group is decreasing at a faster rate - perhaps simply because the rates of the Spanish-speaking group were higher from the start.

That said, what has been the impact of these demographic differences on the intergenerational transmission of Catalan? Vila has analyzed data from several sociolinguistic surveys and has argued that the use of Catalan as the only or predominant language has in fact decreased over three generations (Usos). The first generation, which was born before the Spanish Civil War, used mostly Catalan; the second generation, born between the Civil War and the end of the 1960s, used both Catalan and Spanish; and the third generation, born between the 1970s and the beginning of the 1980 s, tended to use little Catalan. Thus, in three generations, the number of occasional speakers of Catalan has increased, but the number of exclusive speakers has decreased. ${ }^{\text {I2 }}$ In addition, Vila confirmed the role of different birthrates from Torres and showed that there was a decrease in the intergenerational use of Catalan as the exclusive or predominant language in the oldest cohorts (up to the postwar generations) and also at the end of the 196os. Again, the early migratory waves of the 1960 s and the subsequent low birthrate of nationals and migrants may account for these results. Monolingual use of Spanish decreased, however, in favor of occasional use of Catalan, which can be explained by the gradual 
integration of Spanish migrants into Catalan society and the relative success of linguistic policies in favor of Catalan.

The same trend in favor of Spanish as the language of intergenerational transmission can be observed in the data from the Enquesta de la Regió de Barcelona 2000. The data show that for the Barcelona region the number of homogenous Spanish households (with the parents and children speaking in Spanish) (44.3\%) is higher than the number of homogenous Catalan households (25.6\%). In mixed households (with one parent speaking Catalan and the other speaking Spanish), parents transmit either both languages $(6.8 \%)$ or Catalan $(5.0 \%)$, and only to a lesser degree solely Spanish (1.0\%). ${ }^{20}$ These data indicate that the number of speakers does not necessarily increase in Spanish, but since the number of couples who speak Spanish at home is higher, Spanish in the Barcelona region remains more pervasive than Catalan, ${ }^{21}$

A second key aspect of intergenerational transmission is the use of Catalan among the young generations, who will ultimately transmit their language(s) to their offspring. One of the statements reproduced at the beginning of this article - "És que la saben i no la fan servir" - exemplified the disconnection between knowledge and use that has characterized Catalan youth. The statement is supported, moreover, by sociolinguistic research: those generations born during or after the implementation of Catalan linguistic policy laws ( 1983 and 1998) have a relatively high degree of knowledge of Catalan, but their knowledge does not translate into use in public or in informal interpersonal registers (Boix, Triar 210; Bastardas, Ecologia 176 , Comunicacions 317; Vila, Moment 55). Furthermore, to the degree that virtually all youngsters have knowledge of both Catalan and Spanish and increasingly switch between the languages, the young monolingual Catalan speaker has all but disappeared from Catalan universities, (Boix, Triar 205-12, Ideologies 66). All this may be puzzling to many Catalan speakers who have witnessed the growing visibility of the language in society and schools since the democratic transition. However, as Vila (Col-loqui 77) and Bastardas (Comunicacions 318 ) have argued, recent advances in the presence of Catalan

20. The percentages of language transmission in mixed households are for the total population of the Barcelona metropolitan area.

21. The linguistic data from the Enquesta de la Regió Metropolitana de Barcelona zooo have been a matter of controversy and discussion (see Branchadell, Clar; Marí; and Pradilla). Much of the controversy has centered on specific percentages that show advances or declines in the use of Catalan in the Barcelona area. A discussion of intergenerational transmission must consider demographic differences in the linguistic groups. Otherwise, it is clear that Catalan speakers transmit Catalan, and Spanish speakers transmit Spanish. Fabà et al. show that $93 \%$ of Catalan speakers who speak Catalan with their parents speak Catalan with their children, though this does not guarantee successful transmission of Catalan if the Spanish population outweighs the Catalan population. 
are relative to the historical moment that is taken as a reference point and indicate that social norms persist even though the original social structures have changed. Young people have, in general, a limited understanding of the history of linguistic policy and tend to believe that the normalization of Catalan is complete and that linguistic policy is misguided, even exaggerated (Branchadell, Actituds 17).

Be that as it may, the claims regarding young people's knowledge of Catalan deserve further study. Although statistics do indeed indicate that the level of young people's knowledge of Catalan increased between 1986 and 200I, it would be rash to assume that all have full competence in Catalan (i.e., comparable to Spanish); after all, the contexts of acquisition of Catalan can vary significantly. Not surprisingly, early acquisition and use of Catalan at home contributes to greater knowledge and more frequent use elsewhere, whereas late acquisition tends to result in only occasional use of Catalan. The young generations of the late 1990s, whose language at home was likely to be Spanish, generally acquired Catalan later because linguistic policy was not fully active when they were children. As these generations aged, they started to use Catalan, but not to the same degree as those who were raised entirely in Catalan (Vila, Moment).

The relationship between language and representation (socialization, group loyalty, senses of transgression, gender, class, and ideology in general) is especially salient in the case of language use by young speakers (Boix, Triar 203-12 ; Pujolar, Llengua 19, Vas 271-92). Catalan youth who come from monolingual Catalan-speaking households tend to use Catalan when speaking to other Catalan-speaking peers, but they tend to switch to Spanish when Spanish-speaking peers are present. The degree to which they switch is a matter of the youngsters' perception. For instance, Boix found that youngsters did not express a clear preference toward one language or the other (irrespective of their own linguistic affiliation), but in ethnographic observation, he found that individuals chose their most habitual language as the language base for intragroup communication (Triar). For intergroup communication, however, there was more variability in the use of languages, with a tendency to favor Spanish (see de Rosselló's study for similar results).

In sum, intergenerational transmission depends greatly on the demo-linguistic characteristics of the languages in contact and on the representations (as evidenced by their attitudes) that the speakers ascribe to the languages. Both factors are intertwined, given that major exposure to specific social networks may affect the individual's attitudes and behavior regarding what language to use. For instance, in Canada, where the federal government protects both French and English across the country, the use of French outside Quebec is in decline because the social networks of French speakers are more 
disperse (distant from each other) than those of the English speakers. Thus, as French speakers come into contact with English (exogamous relationships, exposure to mass media, and so on), bilingualism increases and the space for French is reduced (Bastardas, Relacions 197). French-speaking parents may still want their children to learn French, but the language at home and, consequently, the language that will be passed onto future generations becomes progressively English. Bastardas draws a parallel between the status of French in Canada and Catalan in Spain and relates it to the increasing power of national languages, such as Spanish, in the context of globalization:

La pregunta, si de cas, és, doncs, no si els immigrats s'assimilaran al català sinó si la poblaciố autòctona pot iniciar un camí lent d'assimilació cap al castellà, no pas perquè així ho vulgui conscientment, sinó com a resultar de les dinàmiques demolingǘstiques esmentades - matrimoni mixt amb pèrdua d'unilingües amb català Lr [primera llengua], augment de la mescla de poblacions, reproducció de la norma intergrupal favorable al castellà, etc. - en un marc estatal i internacional on el castellà és vist com una llengua forta i extensa, capaç de servir en una vasta àrea del planeta.

The question, at any rate is, not whether migrants will assimilate to Catalan but whether the autochthonous population can initiate a slow journey of assimilation toward Spanish, not because this is what they want consciously, but as a result of the mentioned demolinguistic dynamics - mixed marriages with a loss of monolingual Lr [as a first language] Catalan speakers, increase in the mixture of populations, reproduction of the intergroup norm in favor of Spanish, etc. - in a state and international arena in which Spanish is seen as a strong and extensive language, capable of being useful in a vast area of the planet. (Llengua 6$)^{22}$

\section{CONCLUSIONS}

The two most dramatic changes in the sociolinguistic situation of the Catalan language are that the monolingual Catalan youngster seems to have disappeared and that bilingualism tends to be accepted as the norm by the new generations. The presence of immigrants from outside Spain has added a new wrinkle to the complex interrelationship of languages, groups, and individuals, and will become a decisive factor for the sociolinguistic situation of Catalan.

To conclude, I provide some thoughts and suggestions for further research for each of the three challenges to the sociolinguistic situation of Catalan discussed in this article. Regarding the overall circumstances

22. In this respect, Bastardas states that the process of linguistic normalization should be seen as pro-Catalan rather than anti-Spanish (Ecologia 187; see also Mari). 
of Catalan, there has been much progress since the Spanish transition to democracy (Vallverdú's optimism). The political climate in Spain since the last Spanish (2004) and Catalan (2003) elections provides an opportunity to engage in political negotiations whose aim is a higher degree of linguistic diversity in Spain and Europe as a whole. During the first year of the new Catalan autonomous government in 2003-04, controversies surrounding the Catalan language abounded (e.g., the official status of Catalan in the European Union and translation of the European constitution into Catalan and Valencian varieties), but nevertheless some concrete advances were made (e.g., an increase in the number of teachers and schools, the Pla per a la Llengua $i$ la Cohesió Social, and Voluntaris per la llengua). In addition, the Office of Linguistic Policy of the Catalan government launched a new marketing campaign (Dóna corda al catala - Give Catalan a boost) focusing on the interpersonal rather than the institutional use of Catalan. These measures will prove fruitless, however, unless they are capable of bridging the gap between the government and its citizens. In this respect, what is needed is not so much that Catalan be declared one of the official languages of Europe, but rather that citizens' interactions with Spanish and European institutions change in ways that ensure that fundamental (linguistic) rights are respected. New multilingual models, halfway between the traditional territorial and individual models, may be the most appropriate for Catalonia (Bastardas, Ecologia 186-92). According to Bastardas' model, Catalan would have a preeminent role in institutional communication (a partially territorial model) without the exclusion of Spanish, and individuals would have the right to be served in either of the two languages (a partially individual model). This would make it possible both to recover the public area for Catalan and to provide the necessary support for speakers of Spanish who may want to adopt Catalan as their main language (the so-called "new Catalan speakers"). And yet, for this to become a reality, two conditions must obtain: first, the burden must fall on institutions and businesses rather than on individuals, because ultimately institutions and business provide services to individuals (Ecologia 191); and second, linguistic intervention must tackle not only linguistic competence (e.g. through schooling), but also behavior and, especially, linguistic attitudes and ideologies. In sum, a dynamic, non-dichotomous approach to linguistic policy requires attending to the multilingual population of Catalonia, to the political changes in the Spanish and Catalan governments since $2003-04$, and to the lessons learned from more than twenty years of linguistic legislation in Catalonia. ${ }^{23}$ tica) for dynamic ecolinguistic approaches to linguistic diversity applied to Catalan. 
Regarding the other main challenge - the arrival of thousands of immigrants from Africa and Latin America in the late 1990s- I subscribe to Zapata-Barrero's view that immigration is an irreversible process that needs to be accommodated rather than dismissed or ignored. The Catalan autonomous government and other institutions have made an effort to design educational and civic programs in order to bring immigrants and non-immigrants together in a variety of social spaces. And yet, as I have indicated, the Catalan model still has remnants of the weak model of multiculturalism, which sees the other as an isolated given rather than as a member of a dynamic process. The fact that members of immigrant and non-immigrant groups do not always look at each other, as it were, "eye-to-eye" has important repercussions on how identities are constructed, represented, and appropriated. Junyent has noted that most new immigrants to Catalonia come from societies where the immigrants' languages were also often subordinated (e.g., Quichua in Ecuador, Tamazight in Morocco) and that when Catalan speakers switch to Spanish in their interactions with immigrants, they are reinforcing behavior similar to that of those who oppressed the immigrants in their countries of origin (Noves). Thus, from a more dynamic cross-cultural and historical perspective, communication in Catalan might be understood as an empowering tool for immigrants and for Catalans alike.

Changes in intergenerational language transmission are particularly onerous, because they entail changes in the private uses of language. Fishman, in his detailed discussion of the ideological challenges to reversing language shift, has signaled three basic strategies: "all or nothing at all", "anything is better than nothing", and "the right step at the right time" (Threatened 474-83). Explicitly arguing in favor of the last strategy, Fishman insists on the central role of the family in intergenerational transmission (in contrast to an over-investment in education). Thus, in the case of Catalan, it is crucial that new governmental campaigns and legislation consolidate the Catalan educational system while at the same time studying and creating strategies to transmit Catalan in mixed and homogeneous households. The goals of the new campaign, the previously mentioned Dóna corda al catala, include promoting the use of Catalan in interpersonal and informal contexts and focuses on people who already know (some) Catalan but do not use it -mostly, youngsters from Catalonia and new immigrants. The campaign seems to go in the right direction as far as goals (the promotion of Catalan as a language of integration and inter-group communication rather than as a requirement or an imposition), but it remains to be seen how these goals will be implemented.

Assessing the fate of Catalan, or of any other language, is perhaps 
an impossible task, because living languages cannot be separated from their speakers and the territories in which they are spoken. Language expresses, embodies, and symbolizes cultural reality (Kramsch 3 ), and only through the interdisciplinary study of how language and culture interrelate is it possible to investigate how it can be that youngsters know Catalan, but do not use it; how professors change their first (and official) language at the request of a foreign student; and how a young Moroccan girl thinks that Catalan is too hard to pronounce.

\section{LIORENÇ COMAJOAN MIDDLEBURY COLLEGE}

\section{WORKS CITED}

AlONSO, Javier. "La nova immigració a Catalunya (i què significa per als catalans)." Llengua $i$ Ús 24 (2002): 12-19.

AMBLÀs, Sílvia. Anàlisi dels usos $i$ bàbits lingüistics en relació amb els programes d'intercanvi. Bellaterra: Universitat Autònoma de Barcelona, 200I.

ARENY, M. Dolors, et al. "Conclusions de les jornades." Treballs de Sociolingüistica Catalana 17 (2003): 295-307.

BASTARDAS, Albert. "Comunicacions institucionalitzades i comunicacions individulalitzades: la complexitat de l'ús social de les llengües." Treballs de Sociolinguiistica Catalana 17 (2003): 317-22.

"Diversitat biologica i diversitat lingüística: algunes pistes transdisciplinàries per a una socioecologia de les llengües." Diversitats. Llengües, espècies i ecologies. Ed. Albert Bastardas. Barcelona: Empúries, 2004. 13-53.

Ecologia de les llengües. Medi, contacte i dinàmic sociolingüística. Barcelona: Proa, 1996.

" "Llengua escolar i context demosociolingüístic en els joves francòfons al Canadà a fora de Quebec: Algunes alertes per a la situació catalana." Noves SL. Revista de Sociolingüistica (fall 2002): I-II. I0 Mar. 2004 <http://www6.gencat.net/llengcat/noves/hmoztardor/ internacional/bastardas.pdf>.

- "Llengua i noves migracions: les experiències canadenques $i$ la situació a Catalunya." Revista de Llengua i Dret 37 (2002): 153-90. "Política lingüística mundial a l'era de la globalització: diversitat i intercomunicació des de la perspectiva de la "complexitat"." Noves SL. Revista de Sociolingüística (summer 2002): 1-I4. 10 Mar. 2004 <http://www6.gencat.net/llengcat/noves/hmozestiu/metodologia/ bastardas.pdf>.

—. "Les relacions entre política lingüística i comportament lingüístic: 
apunts des dels casos del francès al Canadà a fora de Quebec." Revista de Llengua i Dret 31 (1999): 193-206.

BoIX, Emili. "Ideologies i usos lingüístics entre els joves a Catalunya. Evolució i perspectives de futur." L'ús del català entre els joves. Ed. Joaquim Noguero, Sabadell: Fundació Caixa de Sabadell, 2000. 8I88.

Triar no és trair. Barcelona: Edicions 62, 1993.

BoIX, Emili, and F. Xavier ViLA. Sociolingüistica de la llengua catalana. Barcelona: Ariel, 1998.

BRANCHADELL, Albert. "Actituds juvenils davant la política lingüística." L'ús del català entre els joves. Ed. Joaquim Noguero. Sabadell: Fundació Caixa de Sabadell, 2000. 9-18.

—. "Clar amb el català." Avui r3 June 2003.

BRANCHADELL, Albert, and Jordi PUJOL. "El futur del català a la universitat." Avui 12 Sept. 2003.

CASALS, David. "L'acolliment lingüistic dels participants en programes d'intercanvi universitaris." Llengua i Ús 24 (2002): 43-48.

Centro de Investigaciones Sociológicas. Estudio 2458. Sondeo sobre la juventud española (segunda oleada). Madrid: Centro de Investigaciones Sociológicas, 2003.

COUPLAND, Nikolas. "Introduction: Sociolinguistic Theory and Social Theory." Socilinguistics and Social Theory. Ed. Nikolas Coupland et al. New York: Pearson Education, 200I. I-26.

CRUSCAT, Xarxa. "Les dades lingüístiques dels cens de l'any 200r: alguns dubtes i limitacions." 8 Jan. 2005. <http://www.iecat.net/ cruscat/documents/censol/index.htm>.

DAY, Stephen. Language and Minority Rights. New York: Longman, 2001.

DE Rosselló, Carles. "Catalan or Spanish? Language Choice from Home to School." Selected Proceedings of the First Workshop on Spanish Sociolinguistics. Ed. Lofti Sayahi. Somerville: Cascadilla Press, 2003. 30-42.

Delgado, Manuel. Diversitat i integració. Barcelona: Empúries, 1998. Enciclopèdia Catalana. Gran diccionari de la llengua catalana. Barcelona, 1998: Enciclopèdia Catalana.

FABĂ, Albert, et al. "Identitat i usos lingüístics a Catalunya." Noves SL. Revista de Sociolingüistica (winter 200I). Io Mar. 2004. <http:// www6.gencat.net/llengcat/noves/hmorhivern/ catalana/fabai_6.htm>.

FisHMan, Joshua. Can Threatened Languages Be Saved? Clevedon: Multilingual Matters, 200I.

- Reversing Language Shift. Clevedon: Multilingual Matters, 1991.

Generalitat de Catalunya. Pla Interdepartamental d'Immigració zoor2004. Barcelona: Generalitat de Catalunya, zoor. 
HAMEL, Rainer Enrique. "Políticas del lenguaje y estrategias culturales en la educación indígena." La educación indigena boy. Inclusión y diversidad. Ed. Instituto de Educación Pública de Oaxaca. Oaxaca: Huaxyácac, 1998. 130-67.

Institut d'Estadística de Catalunya. Cens lingüístic 2001. 6 Feb. 2004. $<$ http://www6.gencat.net/llengcat/socio/docs/censling2001.pdf>.

- Estadistica d'Usos Lingüistics 2003. 10 Apr. 2005. <http://www. idescat.net/cat/idescat/publicacions/cataleg/pdfdocs/EULC2003. $\mathrm{pdf}>$.

- Els naixements a Catalunya l'any 2003. I Feb. 2005. <http://www. ced.uab.es/novetat/nota \% 2onatalitat $\% 20$ Catalunya \%202003.pdf $>$. Instituto Nacional de Estadística. Los extranjeros residentes en España. 22 Feb. 2004. <http://www.ine.es/prodyser/pubweb/ext_espa/ ext_espa.htm>.

JUNYENT, M. Carme. "El català: una llengua en perill d'extinció." El català: mirades al futur. Eds. M. Carme Junyent and Virginia Unamuno. Barcelona: Ediciones Universitarias de Barcelona, 2002, 133-50.

"Lingüística genètica." Diversitats. Llengües, espècies i ecologies. Ed. Albert Bastardas. Barcelona: Empúries, 2004. 133-53.

"Les noves migracions i el futur del català." L'Escletxa 2 (2003): 6. KramSCH, Claire. Language and Culture. New York: Oxford UP, 1998. MARÍ, Isidor. "Del debat a l'acció col-lectiva." L'Espill I5 (2003): 84-97.

Ministerio de Educación y Ciencia. Universidades. Estadística universitaria. Datos avance 2003-2004. 23 Jan. 2005 <http://wwwn.mec.es/ educa/jsp/plantilla.jsp?area=ccuniv\&id=EI23>.

MCANDREW, Marie. "School Spaces and the Construction of Ethnic Relations: Conceptual and Policy Debates." Canadian Ethnic Studies 35 (2003): 37 pars. Academic Search Premier. EBSCO. Middlebury College Lib, ro Jan. 2004 <http://www.epnet.com/>.

MURGADES, Josep. "Ment pensant en un cos que poc batega? El català, avui," L'Espill $\mathrm{I}_{5}$ (2003): 77-83.

PASCUAL, Jordi. "La interculturalitat en les polítiques públiques i escolars. El cas de Catalunya." Interculturalitat: Bases antropológiques, socials i polítiques. Ed. Adela Ros. Barcelona: UOC/Pòrtic, 2003. 89-151.

Pradilla, Miquel Ångel. "La llengua catalana a Catalunya: un futur incert." L'Espill Is (2003): 134-42.

PUJOLAR, Joan. "Immigration in Catalonia: The Politics of Sociolinguistic Research." Catalan Review 9.2 (1995): 141-62.

De què vas, tio? Barcelona: Empúries, 1997.

"Llengua i cultura juvenil." L'ús del català entre els joves. Ed. Joaquim Noguero. Sabadell: Fundació Caixa de Sabadell, 2000. 19-26. RECOLONS, Lluís. "Algunes consideracions sobre sèries de dades estadístiques d'estrangers a Catalunya." Llengua i Ús 24 (2002): 20-27. 
Romani, Joan. "Estudis de la Direcció General de Política Lingüística de la Generalitat de Catalunya (1994-2002)." Noves SL. Revista de Sociolingüistica (winter 2002): I-32, 10 Dec. 2004 <http://www6. gencat.net/llengcat/noves/hmozhivern/catalana/romani.pdf $>$.

SAMPER, Lluís, et al. "Éducation et ethnicité: le cas catalan." Relations ethniques et éducation dans les sociétés divisées: Québec, Irlande du Nord, Catalogne et Belgique. Eds. Marie McAndrew and France Gagnon. Montreal: L'Harmattan, 2000. 127-45.

SiguAN, Miquel. Inmigración y adolescencia: Los retos de la interculturalidad. Barcelona: Paidós, 2003.

SILVERSTEIN, Michael. "Language Structure and Linguistic Ideology." The Elements; A Parasessions on Linguistic Units and Levels. Eds. Paul R. Clyne, William F. Hanks, and Carol L. Hofbauer. Chicago: Chicago Linguistic Society, 1979. 193-247.

Strubell, Miquel. "Catalan a Decade Later." Can Threatened Languages Be Saved? Ed. Joshua Fishman. Clevedon: Multilingual Matters. $260-83$.

SubIRATS, Marina. "Els trets lingüístics." Enquesta de la Regió de Barcelona 2000. Dir. Salvador Giner. Barcelona: Diputació de Barcelona, 2002. 180-87.

TERMES, Josep. La immigració a Catalunya i altres estudis d'història del nacionalisme català. Barcelona: Empúries, 1984.

TERRADAS, Jaume. "Valoracions ètiques i polítiques de la diversitat des de l'ecologia." Diversitats: Llengües, espècies i ecologies. Ed. Albert Bastardas. Barcelona: Empúries, 2004. 168-94.

TORRES, Joaquim. "Les enquestes amb contingut sociolingüístic efectuades a Catalunya (1994-2002)." Noves SL. Revista de Sociolingüística (spring 2003): 1-II. 8 Feb. 2004 < http://www6.gencat.net/ llengcat/noves/hmo3primavera/catalana/torres.pdf $>$.

—. "L'ús oral familiar a Catalunya." Treballs de Sociolingüística Catalana 17 (2003): 47-76.

UBACH, Noemí. "Immigrants i estrangers." Treballs de Sociolingüistica Catalana 17 (2003): $275-78$.

United Nations. "Recommendations on Statistics of International Migration." Statistical Papers Series M, No. 58, Rev, I. New York, 1998.

VERNET, Jaume et al. Dret lingüistic. Valls : Universitat Rovira Virgili and Cossetània Edicions, 2003.

VILA, F. Xavier. "Col-loqui." L'ús del català entre els joves. Ed. Joaquim Noguero. Sabadell: Fundació Caixa de Sabadell, 2000. 76-80.

"El moment d'adquisició del català $i$ les seves repercussions sociolingüístiques." L'ús del català entre els joves. Ed. Joaquim Noguero. Sabadell: Fundació Caixa de Sabadell, 2000. 53-6I. "Els usos lingüistics interpersonals no familiars a Catalunya. Estat 
de la qüestió a començament del segle xxI." Treballs de Sociolingüistica Catalana 17 (2003): 77-158.

—. "Hem guanyat l'escola però hem perdut el pati?' Els usos lingüístics a les escoles catalanes," Llengua, Societat $i$ Comunicació I (2004): 8-I5. Is Nov. 2004. <http://www.ub.edu/cusc/LSC/ numeror/Usos_Vila.pdf $>$.

WOOLARD, Kathryn. "Introduction: Language Ideology as a Field of Inquiry," Language Ideologies. Practice and Theory. Eds. Bambi B. Schieffelin, Kathryn A. Woolard, and Paul V, Kroskrity. New York: Oxford University Press, 1998. 3-47.

ZAPATA-BARRERO, Ricard. Multiculturalidad e inmigración. Madrid:

Sintesis, 2004. 